\title{
Stock Market Crash Induced Capital Flight: Experience of an Emerging Economy
}

\author{
Md. Shahadath Hossain ${ }^{1}$, A. K. Enamul Haque ${ }^{1,2}$, \& A. B. M. Munibur Rahman ${ }^{2}$ \\ ${ }^{1}$ School of Business and Economics, United International University, Dhaka, Bangladesh \\ ${ }^{2}$ School of Management, Wuhan University of Technology, Wuhan, China \\ Correspondence: A. B. M. Munibur Rahman, School of Management, Wuhan University of Technology, \#205 \\ Luoshi Road, 430070, Wuhan, Hubei, P.R. China. Tel: 86-136-592-0801. E-mail: munib_30@yahoo.com
}

Received: September 9, 2013

Accepted: November 11, 2013

Online Published: December 23, 2013

doi:10.5539/ijef.v6n1p114

URL: http://dx.doi.org/10.5539/ijef.v6n1p114

\begin{abstract}
Stock Markets of Bangladesh crashed in FY 2010-2011 after a boom. High daily turnover beforecrash brought out hundreds of billions BDT from the capital market, but neither money supply outside the banks nor money deposit in the banks changed accordingly. Overall post-crash scenario created a suspicion that the money which was withdrawn from the capital market flew out of the country. The study attempts to test the hypothesis of capital flight using daily data from August 01, 2010 to July 31, 2011 of three variables: DSE general index (DSEGI), weighted average exchange rate (EXR), and Foreign exchange reserves (FXRES). Augmented Dickey-Fuller (ADF) and Kwiatkowski-Phillips-Schmidt-Shin (KPSS) unit root tests show that variables are in different order of integration, and Johansen cointegration test shows that variables are non-cointegrated. Two variable, DSEGI and EXR, granger causality test fails to reject the hypothesis of no causality, but Toda-Yamamoto (TY) version of Granger non-causality test with a control for Foreign Reserves (FXRES) found unidirectional causality directed from DSE general index to exchange rate, foreign reserves to exchange rate, and foreign reserves to DSE general index. These causal relationships indicate that capital flight occurred and central bank might have camouflaged the issue of capital flight by foreign reserves management to keep exchange rate relatively stable.
\end{abstract}

Keywords: stock market, capital flight, exchange rate, foreign reserve, granger non-causality test, johansen cointegration

\section{Introduction}

Dhaka Stock Exchange General Index (DSEGI) experienced a sharp surge (175.42 percent) from 3,010 points in January 2009 to 8,290.41 points in December 2010. One of the stock market development indicators "Market Capitalization" grew at a rate of 29.5 percent and became as high as 51.5 percent of gross domestic product (GDP). The Market Price-Earning (P/E) ratio for per BDT of earnings grew at the rate of 26.3 percent and became 24.08 in the same period. After December 05, 2010, the stock market scenario started to change dramatically. Stock market indicators such as general index, market capitalization, turnover, and total value traded to GDP ratio experienced a sharp downfall; the only exception was market volatility, which showed an ascending trend. The value of DSE general index lost 3715.43 points within a period of only 3 monthsDecember 5, 2010-February 28, 2011. Many of the stocks lost half of their prices from their peak points. From December 2010 to February 2011, market capitalization declined by 38 percent, turnover slumped by 70 percent, and $\mathrm{P} / \mathrm{E}$ ratio waned by 39 percent. Turnover to Market Capitalization Ratio which measures the liquidity of stock market was 11 percent in December 2010 became 5 percent in March 2011-a decline of 55 percent. 


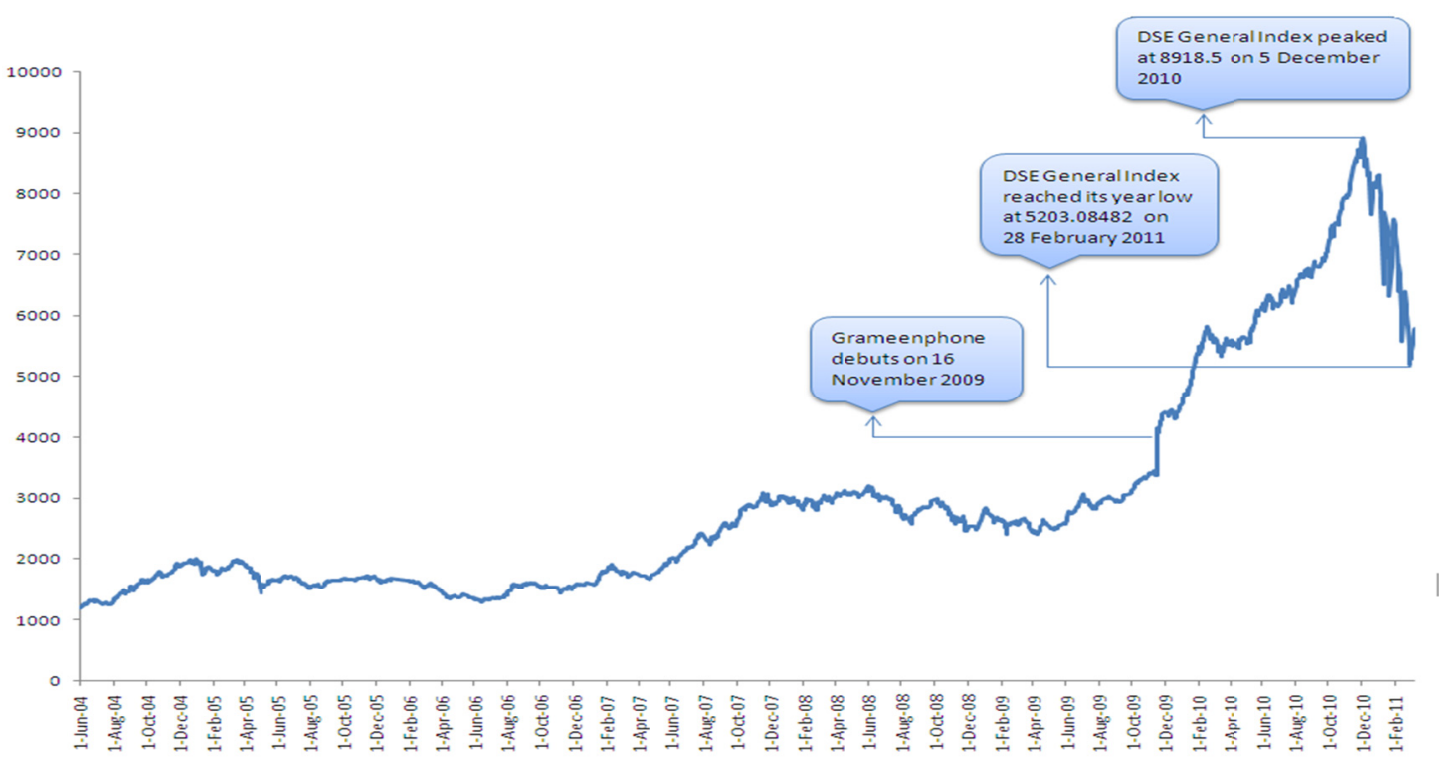

Figure 1. Trend of DSE general index

Source: Dhaka Stock Exchange (DSE) website.

By the end of May 2011, market capitalization and daily turnover declined by 30 percent and 90 percent respectively from the apex. A bubble was created during 2009 and 2010 and burst at the end of December 2010 and the beginning of 2011 (Figure 1).

Several factors from both demand side and supply side-overcrowding of small unskilled investors in the market, manipulating market through frequent changes in face value of share, signaling investors through offering right share and bonus share, playing orchestrated game with Initial Public Offerings (IPOs) that was brought through book building process, and inviting unregulated involvement of commercial banks - created the bubble. Commercial Banks played an influential role in augmenting the bubble through their aggressive involvements (i.e., direct investment and provisions of margin loans) in the capital market- and as such the client base of share market increased manifold (CPD, 2011). Once the bubble was built, a blast was inevitable; right this moment, the market demanded correction. Unfortunately, the correction was big enough to be called a crash. Unlike other stock exchanges in the world, this correction was erratic, quick, and abrupt (Figure2).

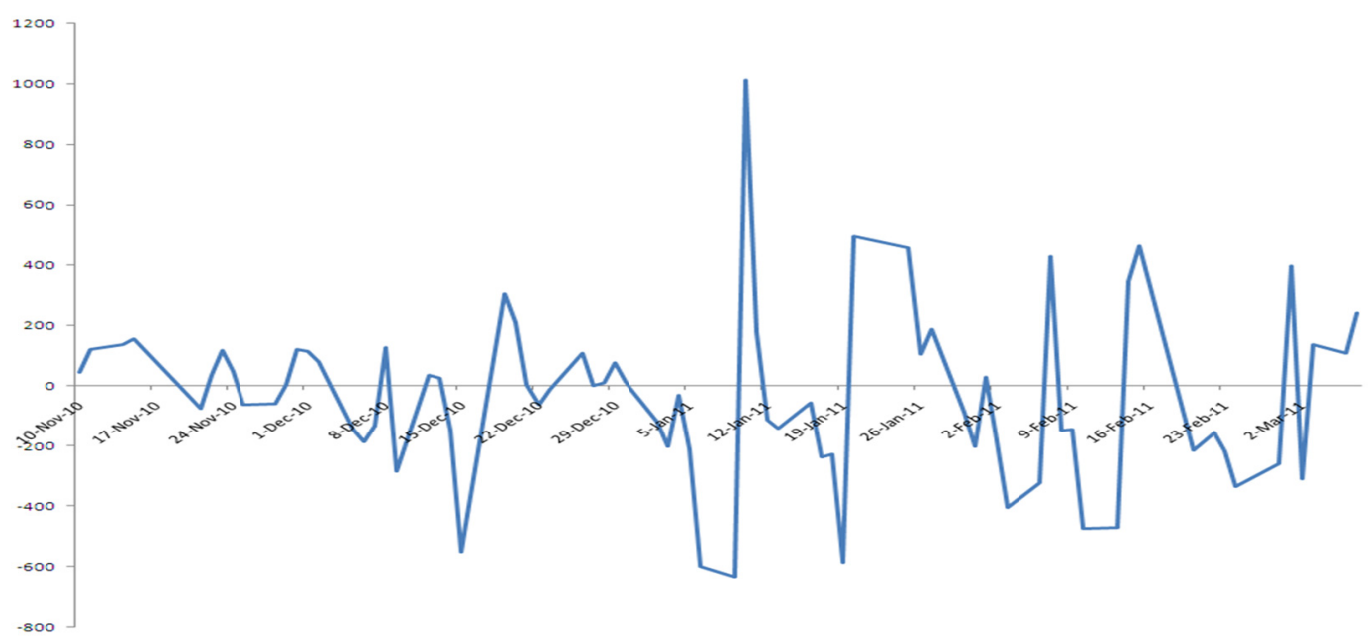

Figure 2. Movement of DSE general index

Source: Dhaka Stock Exchange (DSE) website. 
Within a month, the DSE General Index went down by more than 2000 points. The correction was so erratic that one day DSE General Index fell by record-breaking amount 636 points, whereas the following day index rose by a record barking amount 1013 points.

During the second quarter of FY2011, both average growth of money supply outside the banking system and average growth rate of money deposited in the banks (excluding the inter-bank) were around 2 percent. In contrast, during the third quarter of FY2011, average growth rate of money supply outside the banking system declined ( 3 percent) to negative 1 percent but average growth rate of money deposited in the banks (excluding the inter-bank) remained unchanged ( 2 percent). Usually, overall bank deposits rise in the second quarter of every fiscal year. FY 2011 broke down the tradition; in the context of aggressive withdrawal of money from stock market and rise in interest rate of bank deposits, the growth rate of deposits in the banking system was to go much higher.

Table 1. Currency deposited in the bank and outside of the bank (Billion BDT)

\begin{tabular}{cccccc}
\hline $\begin{array}{c}\text { Fiscal Year } \\
\text { (Quarter) }\end{array}$ & Month & $\begin{array}{c}\text { Currency } \\
\text { Outside Banks }\end{array}$ & $\begin{array}{c}\text { Total Bank Deposit } \\
\text { (excluding } \\
\text { inter-bank) }\end{array}$ & $\begin{array}{c}\text { Change of Currency } \\
\text { Outside Banks }\end{array}$ & $\begin{array}{c}\text { Change of Total Bank Deposit } \\
\text { (excluding inter-bank) }\end{array}$ \\
\hline 2010-11 (Q1) & August & 498.20 & 3425.88 & - & - \\
Q1 & September & 497.38 & 3495.27 & $-0.16 \%$ & $2.03 \%$ \\
Q2 & October & 486.23 & 3572.22 & $-2.24 \%$ & $2.20 \%$ \\
Q2 & November & 532.26 & 3627.24 & $9.47 \%$ & $1.54 \%$ \\
Q2 & December & 529.18 & 3683.65 & $-0.58 \%$ & $1.56 \%$ \\
Q3 & January & 520.84 & 3712.72 & $-1.58 \%$ & $0.79 \%$ \\
Q3 & February & 519.18 & 3764.74 & $-0.32 \%$ & $1.40 \%$ \\
Q3 & March & 518.05 & 3867.79 & $-0.22 \%$ & $2.74 \%$ \\
Q4 & April & 523.54 & 3915.77 & $1.06 \%$ & $1.24 \%$ \\
Q4 & May & 539.59 & 3984.64 & $3.06 \%$ & $1.76 \%$ \\
Q4 & June & 547.95 & 4104.45 & $1.55 \%$ & $3.01 \%$ \\
\hline
\end{tabular}

Source: Bangladesh Bank.

In the overheated market, the value of shares was created out of thin air and the shares were traded much higher than their fundamental value. Suddenly, the market crashed and the value of shares toppled down, but the money used in buying and selling shares did not disappear, and in fact, belonged to the persons who profitably traded on shares. High daily turnover before the crash brought out hundreds of billions BDT from the capital market, but neither the money supply outside the banks nor the money deposit in the banks changed accordingly. Overall, the post-crash scenario created a suspicion that the money which was withdrawn from the capital market flew out of the country by the misused over-invoicing of imported goods, exploiting kerb currency market, money laundering, and some other informal channels and hoarded overseas or stashed as 'Mattress money'. One could argue that the foreign investors could have taken the money out. The capital flow from foreign investors has never been a driving factor for stock market of Bangladesh. The foreign investors stood at maximum 6 percent of the total individual beneficiary owner (BO) account holders that hold at most 1-2 percent ownership of stocks listed in the market. In FY 2011, the outward remittances that were generated from the stock market by the foreign investors amounted to US\$205 million. The market capitalization in December 2011 was US\$49.86 billion. Hence, the amount of fund the foreign investors remitted throughout the year was 0.41 percent of the market capitalization.

It is logical to argue that if there were any stock market manipulation, it had been done for moneymaking and the moneymaker would not have kept the money within the economy as it is not danger free. At the same time, the stock market manipulators would not have kept the money in formal banking channel as it would bring forth their names through crashaftermath investigation. Therefore, the moneymakers were left with two optionshoarding the money overseas or stashing it as 'Mattress money'. Previous studies (Alam \& Quazi, 2003; Sarker, 
2009) on capital flight from Bangladesh identified main reasons of capital flight as political instability, corruption in the tax administration, willful default of bank loans, stock market manipulation, and over-invoicing $\&$ under-invoicing. Capital flight literature refers to several multidimensional problems like low domestic saving and investment, rising unemployment, shrink in tax base, decline in foreign reserve, and lower GDP growth caused by capital flight. Lessard \& Williamson (1987) argued that capital flight implies at least one-for-one reduction in domestic investment. "The best case involves a reduction in the savings to finance domestic investment, of a magnitude essentially equal to the size of the capital flight. Future growth will in consequence be lower. The worst case involves a reduction not just in future growth possibilities but also in the current level of output by some multiple of the size of the capital flight" (Lessard \& Williamson, 1987, p. 224). World Economic Outlook by Deppler and Willamson (1987) expressed clearly that the fundamental economic concern about capital flight, however, is that it reduces welfare in the sense that it leads to a net loss in the total real resources available to an economy for investment and growth. That is capital flight which is viewed as diversion of domestic savings away from financing domestic real investment. As a result, the pace of growth and development of the economy is retarded from what it otherwise would have been. Capital fight is a serious problem for a developing country like Bangladesh and calls for considerable policy intervention (Sarker, 2009). None of the researches could provide any reasonable empirical evidence of capital flight caused by stock markets tumult of 2010-2011. Therefore, it is worth testing whether capital flight occurred or in other words, the intensity of capital flight was augmented by the stock markets tumult of 2010-2011. The objective of this study is to find out whether capital flight from Bangladesh occurred due to stock market tumult within the period selected for the study.

\section{Theoretical Ground of the Study and Literature Review}

Capital is the sum of cash and assets put into production process. Capital flight is the sum of all outflows of domestic capital which, if invested domestically would yield higher social return. Hence, capital flight leads to lower national utility. The aforementioned definition is clearly a very broad definition as it includes all reported and unreported outflows and it may over-estimate the overall impact of capital flight. A narrow definition of capital flight often termed as 'hot money' considers only short-term outflow of funds as capital flight. Capital flight is often defined as the illegal transfer of capital which occurs when traders keep capital abroad by falsification of trade documents (Schneider, 2001). Varman-Schneider (1991) and Schneider (2001) define capital flight as a subset of international asset deployment or portfolio adjustment undertaken in response to an unusual perceived deterioration in risk/return portfolio associated with assets located in a particular country.

The relationship between stock market and capital flight is established through association between exchange rate and share prices and exchange rate and foreign reserves. The theoretical ground of the relationship between stock market and exchange rate is wellestablished but the empirical result is not clear enough as researches found mixed results. The relationship between stock market and exchange market can be explained by 'flow oriented' model and 'portfolio-balance' model. Dornbusch and Fisher (1980) used the flow oriented model to explain the linkage through 'goods market'. They suggested that any variation in the exchange rate affects the competitiveness of the firm by altering the earnings and costs, and hence the stock price. A depreciation of the local currency makes local goods relatively cheaper to the foreigners and hence increases the demand for local goods. Higher export enhances the profit of the firm and eventually the stock price. On the other hand, an appreciation will make the local goods relatively expensive to the foreigners and demand for local goods will fall. Lower export will reduce the profit of the firm and in the end will lower the price of its stock. Alongside, fluctuation in the exchange rate will affect the firm's transaction exposure, which means the value of its future payables, or receivables denominated in foreign currency will be at risk. Hence, in "flow oriented model" direction of the relationship flows from exchange rate to capital market. Branson (1983) and Frankel (1983) advocated that "Portfolio-balance" method or 'stock' approach is the second way of explaining the connection between the stock price and exchange rate. Economic agents allocate their wealth among alternative assets- local currency, and domestic \& foreign securities. Exchange rate works as a controlling factor for asset demand and supply. Equilibrium exchange rate is established through asset demand-supply interaction. Any rise in domestic stock prices will raise the wealth and money (local currency) demand. As money demand goes up, in response interest rate will go up. Higher interest rate attracts foreign capital to flow in, and in response domestic currency appreciates and real exchange rate rises. The reverse happens when stock price falls, and investors try to sell their stocks and convert their money into foreign currency. Demand for foreign currency in exchange of domestic currency increases and in response domestic currency depreciates which leads to fall in real exchange rate. Hence, in "Portfolio-balance" model, direction of the relationship flows from capital market to exchange rate. Now the question is in reality whether the causation runs from capital market to exchange rate or exchange 
rate to capital market or bidirectional.

The causal relationship between stock market and macroeconomic variables is examined thoroughly to find the informational efficiency of the stock market. Most of the works have been done on US markets. Many empirical literatures examined stock price-exchange rate relationship and found inconclusive result. Studies (Aggarwal, 1981; Solnik, 1987; Smith, 1992) showed a significant positive relationship between stock market and exchange market. Conversely, some studies (Franck \& Young, 1972; Bartov \& Bodnor, 1994; Chow et al., 1997) reported that there was no, negative, or very weak relation between stock price and exchange rate.

The first study (Franck \& Young, 1972) that highlighted the relationship between stock price and exchange rates found no relationship using six different exchange rates. Aggarwal (1981) explored the relationship between change in dollar exchange rate and change in the price of stock indices. He used monthly U.S. stock price and the effective exchange rate for the period 1974-1978. Soenen and Hanniger (1988) used monthly stock price and effective exchange rate for a period of 1980-1986 and found a significant negative relationship. Smith (1992) used Portfolio Balanced model to examine the determinants of exchange rate. His model considered values of equities, stocks of bond, and money as important determinants of exchange rate. He has found that equity values have significant influence on exchange rates. On the other hand, money and stock of bond have an insignificant impact on the exchange rates. Bahmani-Oskooee and Sohrabian (1992) used Grangers causality test and found a two-way causal relationship between the U.S. stock market and the exchange rates. A study (Ajayi \& Mougoue, 1996) shows aggregate domestic stock price positively affects domestic currency value in the long run. Conversely, domestic stock price negatively affects exchange rate in the short run. Further study demonstrates (Kate \& Fabiola, 2005) foreign exchange restrictions have insignificant impact on the link between the domestic equity market and foreign exchange markets and the link between domestic and world capital market. Free capital flow is necessary, but not sufficient for international investment; access to market information is also required.

The issue of connection between stock market and exchange rate received considerable attention during the East Asian crisis of 1997-1998. During this period, the world has observed the collapse of emerging markets due to both large depreciation of exchange rate in the exchange market and sharp fall of stock prices in the equity market. This makes researchers cautious about the causal relationship between stock prices and exchange rate. If there is any causal relationship and the causation runs from exchange rate to stock prices, crisis in the stock market can be prevented by controlling exchange rate. Alternatively, if the causation runs from stock prices to exchange rate, then by taking domestic economic policies to stabilize the stock market can prevent the crisis. One study (Abdalla \& Murinde, 1997) based on three Asian countries (India, Korea, and Pakistan) found that exchange rates granger cause stock prices. Further study (Qiao, 1997) used daily stock indices and daily spot exchange rates data of Hong Kong, Tokyo, and Singapore from January 3, 1983 to June 15, 1994 to examine the causal relationship between stock price and exchange rate. He used Granger causality test and found that changes in stock prices were caused by changes in exchange rate in Tokyo and Hong-Kong, but no causality was there in Singapore market for these financial variables.

The intensity of the relationship between exchange rate and foreign reserves depends on the level of intervention done by the monetary authorities. Monetary authorities intervene in the exchange rate transaction to alter the direction of exchange rate volatility. Developing countries are found to be more lenient of foreign reserves variations than exchange rate volatility, which indicates that at time of exchange rate volatility countries use their foreign reserves to intervene in the foreign exchange market. Empirical studies (Levy-Yeyati \& Sturzenegger, 2004); Calvo \& Reinhart, 2002) used foreign reserves fluctuation as a proxy for exchange market intervention. Empirical studies (Dominguez, 1998; Kearns, 2003) suggested two primary channels through which sterilized intervention can control the level of exchange rate: The portfolio balance channel and the signaling channel. Dominguez (1998) argued that according to portfolio-balance models of exchange rate determination, investors diversify their holdings among domestic and foreign assets based both on expected returns and on the variance in returns. As per the theory, as long as foreign and domestic assets are considered outside assets and are imperfect substitutes for each other in investor's portfolios, an intervention that changes the relative outstanding supply of domestic assets will require a change in expected relative returns. This may result in a change in the exchange rate. The signaling channel is utilized by the central bank to affect the exchange rate through dissemination of private information about exchange rate fundamentals (Kearns, 2003). The central bank may have associates in the private sector to intervene in the exchange market for them. In the U.S.A., intervention in foreign exchange market is done by contacting a dealing bank and buying currency at the dealer bank's quoted rate (Lyons, 2001). Nearly half of the Fed's interventions are done secretly (Hung, 1997).

Literature of the relationship between foreign reserves and exchange rate indicates that central banks in 
developing countries intervene into the foreign exchange market to devalue domestic currency to have higher export. They control exchange rate through buying foreign currency for domestic currency in the foreign exchange market. The process is carried out backing by sterilization to encounter inflationary pressure (Basu, 2009). There are contradictory remarks as to which strategy- portfolio balance channel or the signaling channelis more effective. Researchers (Rogoff, 1984) had doubt on the large impact through portfolio balance channel. Many studies (Dominguez \& Franakel, 1993; Evans \& Lyons, 2001) did not find any evidence of such channel, but Ghosh (1992) argued that it was weak. Studies (Mussa, 1981; Dominguez \& Frankel, 1993) found that intervention through signaling channel is substantially stronger than the intervention through portfolio balance channel. Dominguez \& Frankel (1993) found that central banks' intervention strategies could range from direct trades with commercial banks to direct trade through brokers to control the degree of the secrecy of their action.

\section{Data and Method}

\subsection{Data}

This study is primarily based on secondary data. The study comprises daily data from August 01, 2010 to July 31 , 2011. The number of sample days used for the study is 365 . Three variables of the study are daily DSE general index (closing), daily weighted average exchange rate expressed in terms of BDT per dollar, and daily foreign exchange reserves expressed in million US dollar. The data were collected from two different sources. Exchange rate and foreign exchange reserves data were collected from central Bank of Bangladesh-Bangladesh Bank (BB) - and DSE general index (closing) data were collected from Dhaka Stock Exchange.

\subsubsection{Variables Explained}

\section{DSE General Index (DSEGI)}

Dhaka Stock Exchange (DSE) is selected for the study, because it is the main stock exchange of Bangladesh. Daily DSE General Index values have been used in this paper. DSE general index is calculated based on the following equation.

$$
\begin{gathered}
\text { Closing Index }=((\text { Yesterday's Closing Index *Closing Market Cap. })) /(\text { Opening Market Cap. }) \\
\text { Closing Market Cap. }=\sum(\text { Closing Price * Total no. of indexed shares })
\end{gathered}
$$

DGEN including share groups of A, B, G, and $\mathrm{N}$ totals 210 securities out of 260 traded securities. It excludes mutual funds, $\mathrm{Z}$ category shares and corporate bonds.

\section{Exchange Rate (EXR)}

Since most of the Bangladeshi foreign trades are dominated in US dollars, "BDT per US dollar" is used as a representative of exchange rate of Bangladeshi currency. Daily weighted average exchange rate that represents inter-bank spot exchange rate is used in this paper. It is set by the dealer banks based on demand-supply interaction. Bangladesh Bank (BB) also uses it for buy-sell transactions between government and international organizations.

\section{Foreign Reserves (FXRES)}

Daily foreign currency reserves that are held with Bangladesh Bank (BB) have been taken as Foreign Reserves. The amount of foreign currency reserves is expressed in terms of million US dollar.

\subsection{Methodology}

The outflow of domestic fund is as such that it must have affected other macroeconomic variables. The achromatic behaviors of macroeconomic variables have made it difficult to find the missing link. If capital flight occurred so much as suspected within the stipulated time, it can be captured through testing causality between stock prices and other macroeconomic variables. In this paper, Granger's method of testing causality has been used to find the causality and direction of causality between DSEGI, EXR, and FXRES. Causality test shows that whether one variable explains the change in another variable.

At first, two-variable granger causality test is employed. The general specification of the Granger causality test is as follows:

$$
\begin{gathered}
Y_{t}=\beta_{0}+\sum_{i=1}^{n} \propto_{i} Y_{t-i}+\sum_{j=1}^{n} \beta_{j} X_{t-j}+u_{1 t} \\
X_{t}=\lambda_{0}+\sum_{i=1}^{n} \lambda_{i} X_{t-i}+\sum_{j=1}^{n} \delta_{j} Y_{t-j}+u_{2 t}
\end{gathered}
$$

In the first regression equation, $Y_{t}$ is the endogenous variable at time $t$ and $X_{t}$ is the exogenous variables at time $t$ between which causality will be tested; $u_{1 t}$ and $u_{2 t}$ are mutually uncorrelated error terms; $t$ is the time; and 
$i$ and $j$ are the number of lags. The null hypothesis is $\sum \beta_{j}=\sum \delta_{j}=0$ for all $j$ 's (all number of lags) and alternative hypothesis is $\sum \beta_{j} \neq 0$ and $\sum \delta_{j} \neq 0$ which means some of the $\beta_{j}$ and $\delta_{j}$ are not zero. If the estimated coefficient $\beta_{j}$ 's are statistically insignificant but $\delta_{j}$ 's are not so, then $Y$ causes $X$ (unidirectional causality) and if the estimated coefficient $\delta_{j}$ s are statistically insignificant but $\beta_{j}$ 's are not so, then $X$ causes $Y$ (unidirectional causality). On the other hand, if both of the estimated coefficient $\beta_{i}$ 's and $\delta_{i}$ 's are statistically significant, then causality runs both ways (bilateral causality) and if both of the estimated coefficient $\beta_{i}$ 's and $\delta_{i}$ 's are statistically insignificant, then there is no causality between them.

Granger causality test can be applied in a Vector Auto-regression (VAR) form. This allows testing the simultaneity of all the included variables. For a ' $n$ ' time series variables $y_{t}=\left(y_{1 t}, y_{2 t}, \ldots y_{n t}\right)^{\prime}$ is a VAR model of order $\mathrm{p}[\operatorname{VAR}(\mathrm{p})]$ that can be written as $y_{t}=A_{0}+A_{1} y_{t-1}+A_{2} y_{t-2}+\cdots+A_{P} y_{t-p}+u_{t}$.

Where, $\mathrm{p}=$ the number of lag in the system;

$\mathrm{n}=$ the number of variable in the system;

$y_{t}$ is a $(\mathrm{nx} 1)$ vector contain all the variables;

$A_{0}$ is a (nx1) vector of intercepts;

$A_{1}$ is a (nxn) matrix of coefficients;

$u_{t}$ is a (nx1) vector of error terms.

A three variable VAR of order $\mathrm{p}$ could take the form below:

$$
\begin{aligned}
& {\left[\begin{array}{l}
y_{1 t} \\
y_{2 t} \\
y_{3 t}
\end{array}\right]=\left[\begin{array}{l}
\gamma_{1} \\
\gamma_{2} \\
\gamma_{3}
\end{array}\right]+\left[\begin{array}{lll}
A_{11}^{l} & A_{12}^{l} & A_{13}^{l} \\
A_{21}^{l} & A_{22}^{l} & A_{23}^{l} \\
A_{31}^{l} & A_{32}^{l} & A_{33}^{l}
\end{array}\right]\left[\begin{array}{l}
x_{t-1} \\
z_{t-1} \\
y_{t-1}
\end{array}\right]+\ldots+\left[\begin{array}{ccc}
A_{11}^{p} & A_{12}^{p} & A_{13}^{p} \\
A_{21}^{p} & A_{22}^{p} & A_{23}^{p} \\
A_{31}^{p} & A_{32}^{p} & A_{33}^{p}
\end{array}\right]\left[\begin{array}{l}
y_{1 t-p} \\
y_{2 t-p} \\
y_{3 t-p}
\end{array}\right]+\left[\begin{array}{l}
u_{1 t} \\
u_{2 t} \\
u_{3 t}
\end{array}\right]} \\
& {\left[\sum u\right]=\left[\begin{array}{lll}
\sum 11 & \sum 12 & \sum 13 \\
\sum{ }^{\prime} 12 & \sum 22 & \sum 23 \\
\sum^{\prime} 13 & \sum{ }^{\prime} 23 & \sum 33
\end{array}\right]}
\end{aligned}
$$

In this model $y_{1 t}$ does not Granger cause $y_{3 t}$ if either $A_{31}^{i}=0$ and $A_{21}^{i}=0 ; i=1, \ldots, k$ or either $A_{31}^{i}=0$ and $A_{32}^{i}=0 ; i=1, \ldots, k$.

Many empirical tests (for example, Engle \& Granger, 1987) have highlighted that time series data may lead to spurious regression estimation as variables are non-stationary or integrated of order 1 . The test is valid, if the variables are not cointegrated. Hence, the first step would be checking stationarity of the original variables and then test cointegration between them. Besides, the selection of true lag length is a crucial decision for the accuracy of the estimation. The result of Granger causality is highly sensitive to the selection of the lag length. If the chosen lag length is more or less than the true lag length, the irrelevant lags or omission of the lags will give inefficient or biased estimation.

In step one, Augmented Dickey-Fuller (ADF) test and Kwiatkowski-Phillips-Schmidt-Shin (KPSS) (1992) test were conducted to investigate whether the series data are stationary or not. Schwarz Information Criterion (SIC) is used for optimal lag selection to conduct ADF test.

In step two, cointegration among variables of the same order of integration was examined by using Johansen (1991; 1995) cointegration. Johansen method tried to test the existence of long-run equilibrium relationship between non-stationary variables of the same order of integration; therefore, the test was based on the maximum eigenvalue and trace statistics or based on likelihood ratio (LR).

In step three, If the null hypothesis of nonstationarity was rejected and variables of same order of integration were not cointegrated, the standard Granger causality could be applied. On the contrary, if variables were cointegrated (there existed a long run stable relationship), Vector Eerror Correction Model (VCEM) was required to test the granger causality.

There are several drawbacks of using traditional Granger causality test and Error Correction Model (ECM). Giles \& Mirza (1999) have identified that pre-testing for stationarity and cointegration before the Granger causality test can lead to over rejection of a non-causal null, i.e., pretesting for order of integration and cointegration may lead to wrong conclusion of causality. Toda (1995) showed that pretesting for cointegrated rank in Johansen-type Error Correction Mechanism (ECMs) are sensitive to the value of the nuisance parameters, hence causality testing based on the ECM may be severely biased. Furthermore, if variables in the model are in different order of integration, I(0) and I(1), and non-cointegrated then VECM model cannot be implemented. 
Gujarati (2003) stated that when variables are co-integrated the F-statistic to test joint significance might not valid, as the test's coefficients do not have a standard distribution. Enders (2004) argued that in some special cases one can use first differential VAR, which cannot be applied universally as differencing of variables may give unsatisfactory results. To sum up, due to the likelihood of specification bias and spurious regression, I decided not to use standard Granger causality procedure to test the causal relationship between the three time series variables on hand. I used a simple procedure proposed by Toda-Yamamoto (1995). Toda-Yamamoto (TY) method is an alternative method based on Granger non-causality equation but augmented with extra lags determined by the maximum order of cointegration of the variables entered into the model.

Toda-Yamamoto (TY) method is applicable irrespective of cointegration or non-cointegration and order of integration of variables, but this method does not replace the traditional test of unit root and cointegration. TY method involves a Modified Wald (MWALD) test in an augmented VAR model. The underlying idea of TY method is to augment the true lag length (say, $p$ ) of VAR model artificially by the maximum order of integration (say, dmax). Then consider the sum of $p$ and $d \max (p+d \max )$ as a true order of VAR and estimate the model. After that, MWALD procedure is applied to the first $\mathrm{k}$ VAR coefficients to investigate causality. WALD test statistics converges to an asymptotic $\chi^{2}$ distribution. A three variable (say $x, y, z$ ) model employing the Seemingly Unrelated Regression (SURE) framework to estimate VAR (3) is given below:

Employing Seemingly Unrelated Regression (SURE) framework, we estimate VAR (3).

$$
\left[\begin{array}{l}
x_{t} \\
y_{t} \\
z_{t}
\end{array}\right]=\beta_{o}+\beta_{I}\left[\begin{array}{l}
x_{t-1} \\
y_{t-1} \\
z_{t-1}
\end{array}\right]+\beta_{2}\left[\begin{array}{l}
x_{t-2} \\
y_{t-2} \\
z_{t-2}
\end{array}\right]+\left[\begin{array}{l}
x_{t-3} \\
y_{t-3} \\
z_{t-3}
\end{array}\right]+\left[\begin{array}{l}
u x_{t} \\
u y_{t} \\
u z_{t}
\end{array}\right]
$$

To test $z_{t}$ does not cause $x_{t}$, the null hypothesis is stated as-

$$
H_{0}=\beta_{12}^{(1)}=\beta_{12}^{(2)}=0
$$

Alternatively,

Where $\beta_{12}^{(i)}$ are the coefficients of $x_{t-i}, i=1,2$.

$$
H_{1}=\beta_{12}^{(1)} \neq \beta_{12}^{(2)} \neq 0
$$

Lag length determination is critical decision for VAR model. Several lag length selection criteria are defined by different author like, Schwarz Criterion (SC) (1978), Akaike's (1969) Final Prediction Error (FPE), Akaike Information Criterion (AIC), and Hannan-Quinn Information Criterion (HQ) (1979). These criteria primarily indicate the goodness of fit of alternative models. As a result, they should be used as a complement to likelihood Ratio (LR) test. The LR test should be the primary determinant of the number of lags to include.

\section{Estimates and Results}

This part presents the results and estimates of stationarity, cointegration, and TY version of Granger's causality test.

\subsection{Result of Stationarity Test}

In the first step, the stationarity of DSEGI, EXR, and FXRES was tested using ADF test and KPSS test. With Level (plain value), ADF test can be conducted in three forms, e.g., without intercept and trend, with intercept but no trend, and with both intercept and trend; whereas, KPSS test starts with constant no trend, and then constant with trend, first difference with trend and first difference no trend. Estimated results of stationarity test

\begin{tabular}{|c|c|c|c|c|c|c|c|c|c|}
\hline \multirow{2}{*}{$\begin{array}{l}\text { Name of } \\
\text { the Test }\end{array}$} & \multirow[t]{2}{*}{ Variables } & \multicolumn{2}{|c|}{ No constant, no trend } & \multicolumn{2}{|c|}{ Constant, No trend } & \multicolumn{2}{|c|}{ Constant, with trend } & \multicolumn{2}{|c|}{ First Difference, no trend } \\
\hline & & t statistic & $\mathrm{p}$-value & t statistic & $\mathrm{p}$-value & $\mathrm{t}$ statistic & $\mathrm{p}$-value & t statistic & p-value \\
\hline \multirow{3}{*}{$\begin{array}{l}\vec{z} \\
\overrightarrow{2} \\
\overrightarrow{2} \\
2\end{array}$} & DSEGI & -0.13418 & 0.6365 & -1.312071 & 0.6243 & -1.682264 & 0.7563 & -9.988726 & $0.0000 * *$ \\
\hline & EXR & 2.551306 & 0.9975 & 1.957843 & 0.9999 & -1.807409 & 0.6984 & -8.126046 & $0.0000^{* *}$ \\
\hline & FXRES & -0.23343 & 0.6013 & -3.502537 & $0.0087^{* *}$ & -4.004593 & $0.0097 * *$ & -15.0736 & $0.0000 * *$ \\
\hline
\end{tabular}
are shown in table 2 .

Table 2. Result of augmented Dickey-Fuller test, Kwiatkowski, Phillips, Schmidt, and KPSS test of stationarity 


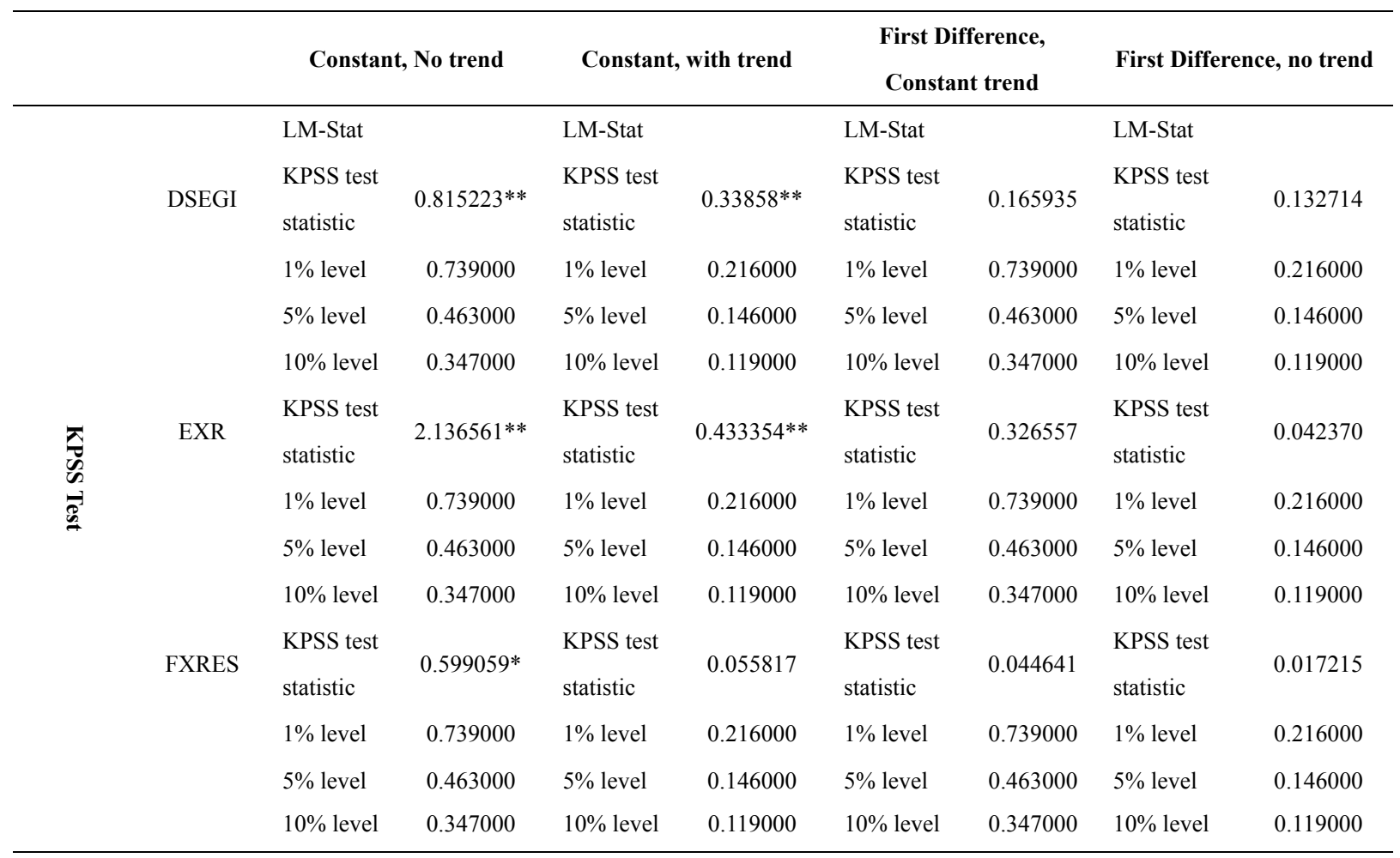

Note: 1) Null hypothesis of ADF test is "Series has a unit root". ** means Null hypothesis is rejected at $1 \%$ level.

2) Null Hypothesis of KPSS test is "Series is stationary". * means Null hypothesis is rejected at 5\% level.

To explain the result of ADF test, at first, DSEGI is considered as $Y$ (endogenous variable) and found that the null hypothesis " $Y_{t}$ is not $I(0)$ " cannot be rejected in all the three forms at 5 percent significance level, as the calculated ADF statistics are lower than critical values of Fuller's table. Acceptance of null hypothesis means that DSEGI is non-stationary or not integrated to order zero. Secondly, EXR is considered as $Y$ (endogenous variable) and found that the null hypothesis cannot be rejected at 5 percent significant level (i.e., EXR is non-stationary or not integrated to order zero). In contrast, the null hypothesis cannot be rejected at 5 percent significance level for FXRES with "no constant and no trend", but the null hypothesis is rejected at 5 percent significance level with "Constant, No trend" and "Constant, with trend". It suggests that FXRES is non-stationary with "no constant and no trend", but stationary with "Constant, No trend" and "Constant, with trend". If a time series is non-stationary (i.e., having unit root), the first differences of the time series will be stationary, which is demonstrated in the last column of ADF test. The first difference estimates of all the variables (i.e., DSEGI, EXR, and FXRES) in all the three forms with "no constant, no trend", "constant, no trend", "constant, with trend" are stationary. In literature, KPSS test is done to cross-check the result of ADF test. KPSS test statistics totally comply with the conclusion reached from ADF test. Both test result shows the maximum level of integration is one, I (1).

\subsection{Lag Length Selection}

Table 3. Lag length selection criteria

\begin{tabular}{ccccccc}
\hline Lag & LogL & LR & FPE & AIC & SC & HQ \\
\hline 0 & -1072.804 & NA & $8.00 \mathrm{E}+10$ & 33.61888 & 33.72008 & 33.65874 \\
1 & -715.6745 & 669.618 & 1508590 & 22.73983 & $23.14462^{*}$ & $22.89930^{*}$ \\
2 & -710.9634 & 8.391589 & 1728668 & 22.87386 & 23.58224 & 23.15292 \\
3 & -704.1153 & 11.55623 & 1858378 & 22.9411 & 23.95308 & 23.33977 \\
4 & -683.8892 & 32.23528 & 1320930 & 22.59029 & 23.90586 & 23.10856 \\
\hline
\end{tabular}




\begin{tabular}{llccccc}
\hline 5 & -675.3605 & 12.79306 & 1361179 & 22.60502 & 24.22418 & 23.24289 \\
6 & -663.7517 & 16.32485 & 1283556 & 22.52349 & 24.44625 & 23.28096 \\
7 & -656.7668 & 9.167786 & 1411782 & 22.58646 & 24.81281 & 23.46353 \\
8 & -647.6368 & 11.1272 & 1469219 & 22.5824 & 25.11234 & 23.57907 \\
9 & -640.6281 & 7.884676 & 1657477 & 22.64463 & 25.47816 & 23.7609 \\
10 & -618.4476 & $22.87374^{*}$ & $1184656 *$ & 22.23274 & 25.36986 & 23.46861 \\
11 & -606.7998 & 10.91973 & 1202814 & 22.15 & 25.59071 & 23.50547 \\
12 & -594.1109 & 10.70625 & 1214918 & 22.03472 & 25.77903 & 23.50979 \\
13 & -590.3839 & 2.795279 & 1680963 & 22.1995 & 26.2474 & 23.79417 \\
14 & -567.5212 & 15.00368 & 1337515 & $21.76629 *$ & 26.11779 & 23.48056 \\
\hline
\end{tabular}

Note: * indicates lag order selected by the criterion. LR: sequential modified Likelihood Ratio (LR) test statistic (each test at 5\% level); FPE: Final prediction error; AIC: Akaike information criterion; SC: Schwarz information criterion; HQ: Hannan-Quinn information criterion

The sequential modified Likelihood Ratio (LR) test statistic and Final Prediction Error (FPE) found that lag10 is the optimal length. After finding true lag length and order of integration, VAR model is estimated, and after that the VAR residual serial correlation test is performed. At lag 10 VAR estimates are severely affected by serial correlation test. VAR residual serial correlation test is performed again to identify the lag length at which serial correlation is removed. It was found that at lag 12 serial correlations is removed and VAR is very close to dynamic stability (Appendix-A: Inverse Root of AR Characteristics Polynomial).

\subsection{Result of Cointegration Test}

Johansen cointegration test is performed on two integration order one or I(1) variables DSEGI and EXR. Both trace statistic and max-Eigen statistic shows there is no cointegration between them (table 4). Hence, it can be concluded that DSEGI and EXR have no long run equilibrium relationship.

Table 4. Johansen cointegration test

\begin{tabular}{lllllll}
\hline No. of Cointegrations & Trace Statistics & Critical Value (5\%) & P-Value & $\begin{array}{l}\text { Max Eigen } \\
\text { Statistics }\end{array}$ & Critical Value (5\%) & P-Value \\
\hline None & 7.464941 & 25.87211 & 0.9895 & 4.754509 & 19.38704 & 0.9901 \\
At most 1 & 2.710432 & 12.51798 & 0.9090 & 2.710432 & 12.51798 & 0.9090 \\
\hline
\end{tabular}

Notes: a) The first column represents the number of cointegrating vectors.

b) The P-value is from MacKinnon-Haug-Michelis (1999).

c) Lag selection ( $\mathrm{k}$ ) is based on LR and FPE, where $\mathrm{k}=12$.

\subsection{Result of Causality}

At first, hypothesis of capital flight is tested with only two variables DSEGI and EXR by using standard Granger causality test with first difference model as both DSEGI and EXR are nonstationary. There is no causal relationship is found with an optimal lag of 15 selected by SIC criteria. Monetary authority may make an effort to stabilize exchange rate through foreign reserves management and if it is so another control variable "Foreign reserves position" should be included in the causality model.

\subsection{Result of TY Granger Non-Causality Test}

After controlling foreign reserve (FXRES) estimating standard granger causality seems unfeasible as FXRES is a stationary and DSEGI and EXR are nonstationary. Therefore, an estimation of the VAR model is done with 12 lags and exogenous variable of lag 13 (lag $p=12$ and $d \max =1, p+d \max =13$ ) of all the variables to augment the VAR. From the estimated VAR the Block Erogeneity Wald Test is performed to find the causality and direction of causality (see Table 5). The first set of estimates whether EXR and FXRES cause DSEGI show that EXR does not cause DSEGI at 5 percent significance level, but FXRES causes DSEGI at 5 percent significance level. It suggests foreign reserves (FXRES) contain useful information to predict the value of DSEGI (stock prices), 
whereas exchange rate (EXR) does not contain useful information to predict the value of DSEGI.

Table 5. Toda-yamamoto granger causality test

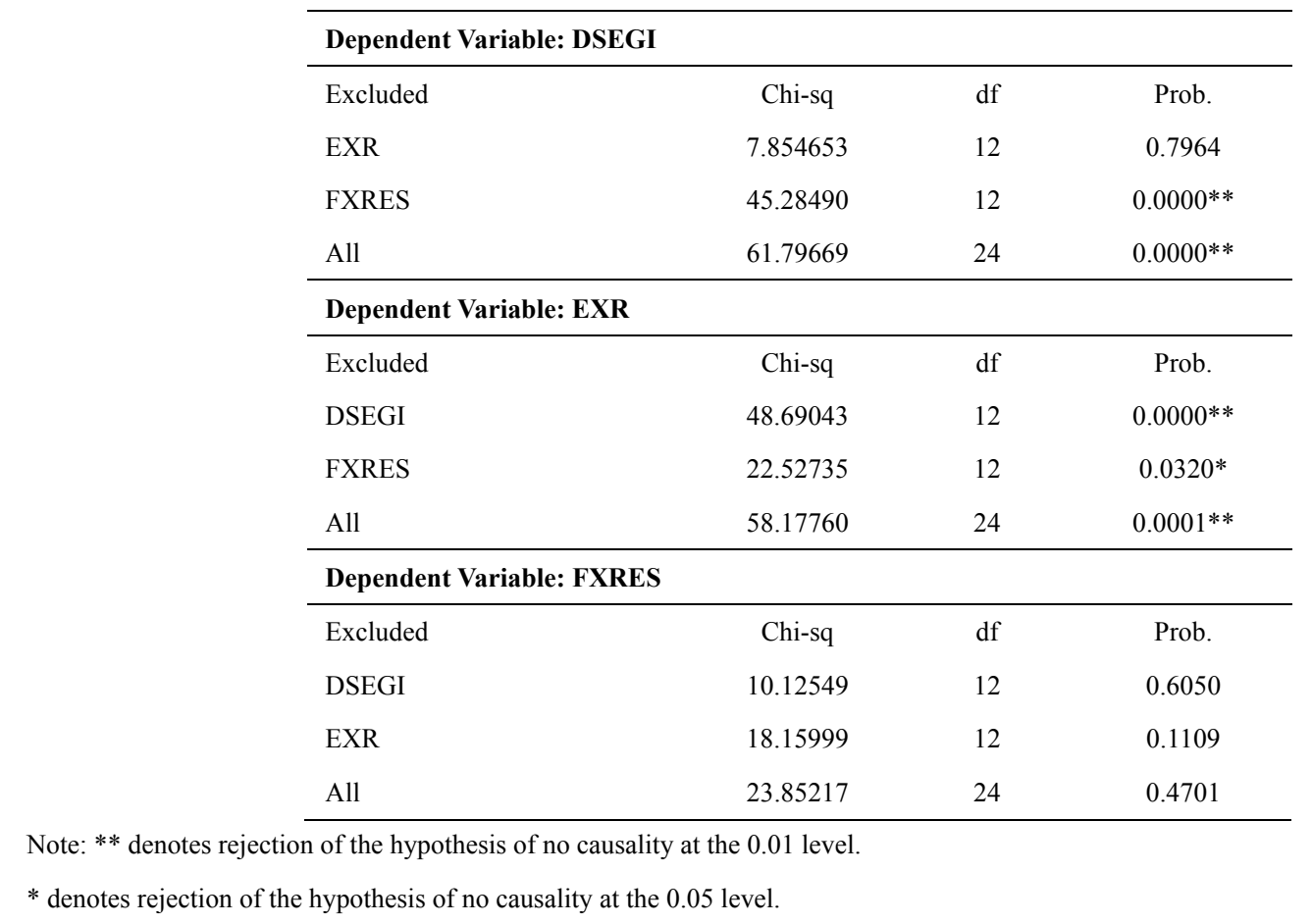

The second set of estimates whether DSEGI and FXRES cause EXR show that both foreign reserves (FXRES) and exchange rate (EXR) causes DSEGI at 5 percent significance level. It suggests that exchange rate and foreign reserves contain useful information for forecasting the values of stock prices. The third set of estimates whether DSEGI and EXR cause FXRES show none of the variable cause foreign reserves at 5 percent significance level. It suggests that DSEGI and exchange rate (EXR) do not contain useful information for forecasting foreign reserves position. The direction of causality runs from DSE general index to exchange rate, foreign reserves to exchange rate, and foreign reserves to DSE general index, whereas there runs no causality from exchange rate to DSE general index, DSE general index to foreign reserves, and exchange rate to foreign reserves. This indicates that there is unidirectional causal relationship between the variables (Table 6).

Table 6. Direction of causality

\begin{tabular}{ccccc}
\hline \multicolumn{2}{c}{ Direction of Causality } & Chi-sq Statistics & p-value \\
\hline DSEGI & $\rightarrow$ & EXR & 48.69043 & $0.0000^{* *}$ \\
FXRES & $\rightarrow$ & EXR & 22.52735 & $0.0320^{*}$ \\
FXRES & $\rightarrow$ & DSEGI & 45.28490 & $0.0000^{* *}$ \\
EXR & $\sim$ & DSEGI & 7.854653 & 0.7964 \\
DSEGI & $\sim$ & FXRES & 10.12549 & 0.6050 \\
EXR & $\sim$ & FXRES & 18.15999 & 0.1109 \\
\hline
\end{tabular}

Note: Arrow $(\rightarrow)$ indicates the direction of causality and Tilde $(\sim)$ indicates no causal relationship.

According to "flow oriented" model, the causality runs from exchange rate to capital market, whereas according to the "Portfolio-balance" method direction of the relationship flows from capital market to exchange rate. As the result above shows, causality running from DSE general index to exchange rate complies with Portfolio-balance 
method. In countries like Bangladesh where outflow of fund outside of the country is restricted, Portfolio-balance method becomes impotent and merely a paper based concept. In a financial environment where flow of domestic funds is restricted, foreign investment in capital market is insignificant, and the long run equilibrium relationship between the DSE general index and exchange rate is absent, and change in stock prices bring change in exchange rate is clearly indicating that capital flight occurred.

If hundreds of billions BDT flew out from Bangladesh, it must have caused sharp rise in exchange rate, but exchange rate did not respond accordingly. Causality running from foreign reserves to exchange rate explains the latent behavior of exchange rate. Central bank (Bangladesh Bank) has supplied enough foreign reserves to keep exchange rate stable. It indicates Bangladesh Bank has camouflage the issue of capital flight by foreign reserves management to keep exchange rate relatively stable. Stock market crash led shift in dollar demand intended to push exchange rate up and on the contrary, dollar supply from foreign reserves shifted accordingly to keep exchange rate to remain relatively stable. These moves of DSE general index led dollar demand and dollar supply from foreign reserves caused an unusual causal relationship between foreign reserves and DSE general index. The causality running from foreign reserves to DSE general index indicates that foreign reserves is indirectly explaining the values of DSE general index by explaining the values of exchange rate.

\section{Conclusion}

The study attempts to test the hypothesis of capital flight using daily data of DSE general index, weighted average exchange rate, and foreign exchange reserves. Augmented Dickey-Fuller (ADF) and KwiatkowskiPhillips-Schmidt-Shin (KPSS) unit root tests are employed to test stationarity of the variables and found that variables are in different order of integration. Johansen cointegration test is employed and found that variables are non-cointegrated. Two variables standard granger causality test with DSRGI and EXR ended up with no causal relationship. A second hypothesis was formed considering that Bangladesh bank may make an effort to stabilize exchange rate through foreign reserves management. After controlling Foreign Reserves (FXRES) variable, Toda-Yamamoto (TY) version of Granger non-causality test is utilized and unidirectional causal relationships among the variables were found moving from DSE general index to exchange rate, foreign reserves to exchange rate, and foreign reserves to DSE general index. This finding resists rejecting the non causal hypothesis and helps to conclude that capital flight occurred and Bangladesh Bank's strategy to keep the exchange rate stable might have camouflaged the issue of capital. This discovery has opened up interesting linkages among stock market, exchange rate and foreign reserves. Capital flight reduces domestic savings and investment, raises unemployment, shrinks tax base, and consequently current level of output and future growth potentials run down. Therefore, policymakers should make macroeconomic policies considering the linkages among stock market, exchange rate and foreign reserves to maximize social welfare.

\section{References}

Abdalla, I. S. A., \& Murinde, V. (1997). Exchange rate and stock price interactions in emerging financial markets: Evidence on India, Korea, Pakistan, and Philippines. Applied Financial Economics, 7, 25-35. http://dx.doi.org/10.1080/096031097333826

Aggarwal, R. (1981). Exchange rates and stock prices: A study of the US capital markets under floating exchange rates. Akron Business and Economic Review, Fall, 7-12.

Ahmed, M. F. (2000). Emerging stock market and the economy. South East Asian studies series. Japan: Nagasaki University.

Ahmed, M., \& Imam, M. (2007). Macroeconomic factors and Bangladesh stock market: Impact analysis through cointegration approach. International Review of Business Research Papers, 3(5), 21-35.

Ajayi, R. A. (1998). On the relationship between stock returns and exchange rates: Tests of Granger Causality. Global Finance Journal, 9, 241-51. http://dx.doi.org/10.1016/S1044-0283(98)90006-0

Ajayi, R. A., \& Mougoue, M. (1996). On the dynamic relation between stock prices and exchange rates. Journal of Financial Research, 19, 193-207.

Akaike, H. (1969). Fitting autoregressive models for prediction. Annals of the Institute of Statistical Mathematics, 21, 243-247. http://dx.doi.org/10.1007/BF02532251

Alam, I., \& Quazi, R. (2003). Determinants of capital flight: An econometric case study of Bangladesh. International Review of Applied Economics, 17(1), 85-103. http://dx.doi.org/10.1080/713673164

Ali, M. (2011). Impact of micro and macroeconomic variables on emerging stock market return: A case on Dhaka Stock Exchange (DSE). Interdisciplinary Journal of Research in Business, 1(5), 8-16. 
Bartov, E., \& Bodnar, G. M. (1994). Firm valuation, earnings expectations, and the exchange-rate exposure effect. Journal of Finance, 49, 1755-1785. http://dx.doi.org/10.1111/j.1540-6261.1994.tb04780.x

Basher, S. (2007). Time-varying volatility and equity returns in Bangladesh stock market. Applied Financial Economics, 17(17), 1393-1407. http://dx.doi.org/10.1080/09603100600771034

Basu, K. (2009). The mechanics of central bank intervention in foreign exchange markets. CAE Working Paper No.09-02.

BD Experts. (2009). Report on Dhaka Stock Exchange (DSE). Retrieved from http://www.bd-experts.com/ShowArticle.aspx?ID=91\&AspxAutoDetectCookieSupport=1

Branson, W. H. (1983). Macroeconomic determinants of real exchange rate risk. In R. J. Herring (Ed.), Managing foreign exchange rate risk. Cambridge: Cambridge University Press.

Calvo, G. A., \& Reinhart, C. M. (2002). Fear of floating. Quarterly Jurnal of Economics, 117(2), 379-408. http://dx.doi.org/10.1162/003355302753650274

Central Depository Bangladesh Limited. (2011). Overview. Retrieved December 25, 2011, from http://www.cdbl.com.bd/overview.php

Centre for Policy Dialogue. (2011). State of the Bangladesh economy in FY2010-11. Retrieved on December 05, 2011, from http://www.cpd.org.bd/downloads/IRBD_FY11.pdf

Chow, E. H., Lee, W. Y., \& Solt, M. S. (1997). The exchange rate risk exposure of asset returns. Journal of Business, 70, 105-123. http://dx.doi.org/10.1086/209710

Chowdhury, A. R. (1994). Statistical properties of daily returns from Dhaka stock exchange. Bangladesh Development Studies, 26, 61-76.

Deppler, M., \& Williamson, M. (1987). Capital flight: Concepts, measurement, and issues. IMF studies for The world Economic Outlook, 39-58.

Dhaka Stock Exchange Ltd. (2011). Monthly Reviews for July, 2011. Retrieved December 25, 2011, from http://www.dsebd.org/july_11.php

Dominguez, K. M. (1998). Central Bank Intervention and Exchange Rate Volatility. Journal of International Money and Finance, 17, 161-190. http://dx.doi.org/10.1016/S0261-5606(97)98055-4

Dominguez, K. M., \& Frankel, J. A. (1993, December). Does foreign-exchange intervention matter? The portfolio effect. American Economic Review, 83(5),1356-1369.

Dornbusch, R., \& Fisher, S. (1980). Exchange rates and the current account. American Economic Review, 70, 960-971.

Engle, R. F., \& Granger, C. W. J. (1987). Cointegration and error correction: Representation, estimation and testing. Econometrica, 55, 251-277. http://dx.doi.org/10.2307/1913236

Evans, M. D., \& Lyons, R. K. (2001). Portfolio balance, price impact, and secret intervention. Working Paper No. 8356. Retrieved from http:// www.nber.org/papers/w8356

Fama, E. (1970). Efficient capital markets: A review of theory and empirical work. Journal of Finance, 25, 383417. http://dx.doi.org/10.2307/2325486

Frank, P., \& Young, A. (1972). Stock price reaction to multinational firms to exchange realignments. Financial Management, 24, 459-464.

Frankel, J. A. (1983). Monetary and portfolio balance models of exchange rate determination. In J. S. Bhandari, \& B. H. Putnam (Eds.), Economic interdependence and flexible exchange rates. Cambridge: MIT Press.

Ghosh, A. R. (1992). Is it singaling? Exchange intervention and the dollar-deutschemark rate. Journal of International Economics, 32, 201-20. http://dx.doi.org/10.1016/0022-1996(92)90017-E

Gujarati, D. N. (2003). Basic econometrics (4th ed.). (pp. 868-884). New York: The McGraw-Hill.

Hung, J. (1997) Intervention strategies and exchange rate volatility: A noisy trading perspective. Journal of International Money and Finance, 16.

Investoprdia. (2011). Price-Earnings Ratio-P/E Ratio. Retrieved December 25, 2011, from http://www.investopedia.com/terms/p/price-earningsratio.asp\#ixzz1j5fPN9vy

Kate, P., \& Fabiola, R. (2005). Stock prices and exchange rate dynamics. Journal of International Money and 
Finance, 24, 1031-1053. http://dx.doi.org/10.1016/j.jimonfin.2005.08.001

Kearns, J., \& Rigobon, R. (2002). Identifying the efficacy of central bank interventions: Evidence from Australia and Japan. Working Paper No.19062.

La Porter. (1997). Legal determinants of external finance. Journal of Finance, 54, 471-517.

Lessard, R. D., \& Williamson, J. (1987). Capital flight: The problem and policy responses. In R. D. Lessard \& J. Williamson (Eds.), The problem and policy responses. Institute of International Economics.

Levine, R., \& Zervos, S. (1998). Stock markets, bank, and economic growth. American Economic Review, 537558.

Levy-Yeyati, E., \& Sturzenegger, F. (2004). Classifying exchange rate regimes: Deeds vs words. European Economic Review, 49(6), 1603-1635. http://dx.doi.org/10.1016/j.euroecorev.2004.01.001

Lyons, R. K. (2001). The microstructure approach to exchange rates. Cambridge: The MIT Press.

Malliaris, A. G., \& Jorge, L. U. (1992). The international crash of October 1987: Causality tests. Journal of Financial and Quantitative Analysis, 27(3), 353-364. http://dx.doi.org/10.2307/2331324

Mohsen, B., \& Sohrabian, A. (1992). Stock prices and the effective exchange rate of the dollar. Applied Economics, 24, 459-464. http://dx.doi.org/10.1080/00036849200000020

Muhammad, N., \& Rasheed, A. (2011). Stock prices and exchange rates: Are they related? Evidence from South Asian countries. The Pakistan Development Review, 41(4), 535.

Mussa, M. (1981). The role of official intervention (pp. 28-35). New York: Group of Thirty.

Phylaktis, K., \& Ravazzolo, F. (2005). Stock prices and exchange rate dynamics. Journal of International Money and Finance, 24, 1031-1053. http://dx.doi.org/10.1016/j.jimonfin.2005.08.001

Qiao, Y. (1997). Stock prices and exchange rates: Experience in leading East Asian financial centers-Tokyo, Hong Kong and Singapore. Singapore Economic Review, 41, 47-56.

Rogoff, K. (1984). On the effects of sterilized intervention: An analysis of weekly data. Journal of Monetary Economics, 14,133-50. http://dx.doi.org/10.1016/0304-3932(84)90056-4

Sarker, A. (2009). Capital flight from Bangladesh: Policy suggestions for central bank. Thoughts on Economics, 18(4), 59-75.

Schneider, B. (2001). Measuring capital flight: Estimates and interpretations. London: Overseas Development Institute. Retrieved from http://www.odi.org.uk/publications/working papers/wp194 maintext.pdf

Securities and Exchange Commission. (2011). About SEC. Retrieved on December 25, 2011, from http://www.secbd.org/about.htm

Solnik, B. (1987). Using financial prices to test exchange rate models: a note. Journal of Finance, 42, 141-149.

Schwarz, G. (1978). Estimating the dimension of a model. The Annals of Statistics, 5, 461-464. http://dx.doi.org/10.1111/j.1540-6261.1987.tb02555.x

Sonnen, L. A., \& Hennigar, E. S. (1988). An analysis of exchange rates and stock prices: The US experience between 1980 and 1986. Akron Business and Economic Review, 19, 716.

Toda, H. Y., \& Yamamoto, T. (1995). Statistical inference in vector autoregressions with possibly integrated processes. Journal of Econometrics, 66, 225-250. http://dx.doi.org/10.1016/0304-4076(94)01616-8

Varman-Schneider, B. (1991). Capital flight from developing countries. Boulder CO: Westview Press.

\section{Appendix}

Appendix A. Residual based serial correlation test and inverse root of AR characteristics polynomial

\begin{tabular}{lcl}
\hline Lags & LM-Stat & Prob. \\
\hline 1 & 3.755642 & 0.9267 \\
2 & 15.52291 & 0.0775 \\
3 & 8.169611 & 0.5171 \\
4 & 3.763776 & 0.9263 \\
\hline
\end{tabular}




\begin{tabular}{lll}
\hline 5 & 6.513826 & 0.6876 \\
6 & 2.599405 & 0.9781 \\
7 & 12.10553 & 0.2074 \\
8 & 4.553890 & 0.8713 \\
9 & 4.124975 & 0.9030 \\
10 & 7.189530 & 0.6174 \\
11 & 3.188066 & 0.9564 \\
12 & 4.666340 & 0.8624 \\
13 & 3.882520 & 0.9190 \\
\hline
\end{tabular}

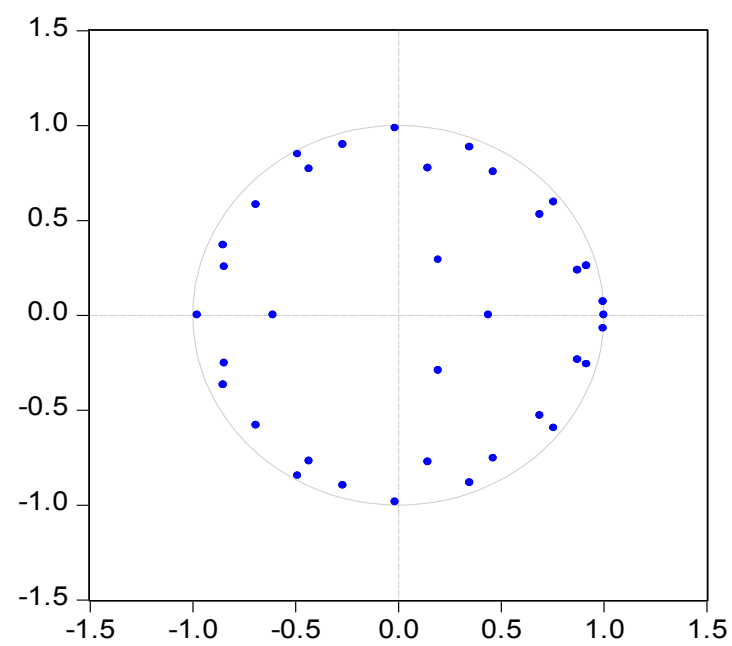

Figure A. Inverse roots of AR characteristic polynomial

Appendix B. Two variables granger causality test

\begin{tabular}{lccc}
\hline Null Hypothesis: & Obs & F-Statistic & Prob. \\
\hline DEXR does not Granger Cause DDSEGI & \multirow{2}{*}{55} & 1.02242 & 0.4669 \\
DDSEGI does not Granger Cause DEXR & & 1.34298 & 0.2523 \\
\hline
\end{tabular}

\section{Copyrights}

Copyright for this article is retained by the author(s), with first publication rights granted to the journal.

This is an open-access article distributed under the terms and conditions of the Creative Commons Attribution license (http://creativecommons.org/licenses/by/3.0/). 